\title{
Critical Evaluation of the Contemporary Scholars' Fatwas on Substitution of Gold Dinar for Banknotes
}

\author{
OLOROGUN, L.A* \& AKHTARZAITE ABDUL AZIZ1
}

\begin{abstract}
Hard currency ('umlah) plays an essential role in any modern economy. The introduction of money as a means of remuneration successfully eliminated the problems posed by traditional barter trade. Gold and silver became the most widely accepted and circulated form of money in the medieval world, stored in the treasuries of the kings and the wealthy and powerful. In 1971 the US government abolished the Bretton Woods system and exchanged with the floating or fiat economy system which soon became the standard currency system worldwide. Disappointingly, no Muslim government produced legal rulings (fatwas) which rejected the legality of the fiat system and demanded the return to gold and silver backed currency. The single fatwa issued in Saudi Arabia in 1985 concluded that paper currency had completely replaced gold and silver and that all previous Islamic legal rulings issued on gold and silver were now applicable to paper currency. This paper study critically evaluates the 1985 fatwa, questions its legal validity and concludes that only a solid gold and silver currency fulfills the legal requirements of an Islamic currency of which all Muslim economies should adopt and protect.
\end{abstract}

Keywords: Substitution, Gold \& Silver, Banknotes, Foreign Exchange, Contemporary Muslim legal thought.

Money (numlah) is defined as anything that has value and serves as a means of exchange which is durable and accepted as currency by the public. Historically, exchange started in its most primitive form as barter trade where both services and commodities were traded. These forms of transactions created numerous problems, such as the difficulty of ensuring equality between exchangeable goods and services, the coincident of want and the issue of quantity. In an effort to solve such problems, local communities created different means of measurement and payment for both goods and services. They varied from precious stones, African cowries to widely established and circulated gold and silver currency such as the dinar and dirham which later become the standard currency of the Muslim world united under the khilafah.

Islamic civilization appeared as an innovative force which changed many old Arabic customs. However, Prophet Muhammad retained some aspects of the old culture which did not violate Islamic teachings and could be preserved and integrated. Among these old practices was use currency in the form of the gold dinar and the silver dirham circulated in ancient Persia or Mesopotamia (Ibn Khaldun

${ }^{1}$ Olorogun, L.A* Ph. D. (Corresponding Author), Department of Economics and Finance, Faculty of Economics, Administrative, and Social Sciences, Istanbul Gelisim University, Cihangir, Şehit Jandarma Komando, J. Kom. Er Hakan Öner Sk. No:1, 34310 Avcllar/İstanbul, TURKEY. Email: laolorogun@gelisim.edu.tr; Akhtarzaite Abdul Aziz, Ph. D., Kulliyyah of Islamic Revealed Knowledge and Human Sciences International Islamic University Malaysia, Jalan Gombak, 53100, Kuala Lumpur, MALAYSIA. Email: akhtarzaite@iium.edu.my

https://doi.org/10.24035/ijit.20.2021.215 
1406, 651-664). Gold and silver had enduring value and were thus considered stable currencies. Allah revealed to the Prophet that His approval of mankind using these two solid metals as money, irrespective of its origins from polytheistic civilizations. Allah admonishes in the Quran (al-Taubah: 34) those "Who hoard up gold and silver and spend it not in the way of Allah". Gold and silver are also mentioned in another verse: "Among the people of the scripture [Jews and Christian] is he who, if entrusted with a great amount of wealth [gold and silver], will readily pay it back; and among them there is he who, if entrusted with a single silver coin will not repay it unless you constantly stand demanding". (Ali-'Imran: 75). Prophet Muhammad was reported to have said: "A time is certainly coming over mankind when there will be nothing left useful for exchange save the dinar and dirham" (Musnad Ahmad ibn Hanbal, Vol. 4, 133: 17240).

From the above undisputable sources, it is clear that gold and silver were considered legitimate currency and means of assurance (trust) by the Prophet himself. The ultimate goal of Islam in general and an Islamic economic and financial system in particular is to seek the favour and mercy of the Creator. This criterion is the dividing line between earlier civilizations that adopted the use of gold and silver as a mean of exchange from that of Islamic civilization. As correctly pointed out by Zarqa (1976), production and profit in an Islamic system is not an end in itself but a means. The driving force of common economic systems is usually profit while that of Islam is justice and ultimately the welfare of the community.

Islamic civilization is not the only civilization which emerged using gold and silver as currency. The Western world emerged as a growing economic power using gold as a means of exchange and only quite recently changed to paper currency backed by gold deposits. This change was based on modern economic theory within a secular framework of governance and culture. In 1821 the British government confirmed the use of gold and silver as a means of exchange and other countries followed suit. Unfortunately, after the great depression of 1929 the British government first announced the abolition of gold as a means of transactions (Hossein 2007; Bernstein 2008), with other European countries following. When Europe's governments abolished the use of gold as a medium of exchange, gold owners were requested to exchange their gold for government notes at discounted rates and in case of failure to do so incur fines and imprisonment. In 1933 the US government de-valued gold by $41 \%$, while Britain had devalued the value of gold by $30 \%$ in 1930 and equally the French Franc was devalued by $30 \%$ and the Italian Lira by $41 \%$ (Hossein 2007).

Despite these developments, gold and silver remained strong until 1944 when the Bretton Woods system of exchange was introduced and the value of an ounce of gold was fixed at \$35. In 1971, 27 years later, the US unilaterally abolished the Bretton Woods system and shifted to fiat or floating exchange monetary system which further de-valued gold as a currency. This paper study critically evaluates the 1985 fatwa, questions its legal validity, and evaluates its effects on Muslim economies disadvantages and intellectual capacity compare to the western economic and intellectual current favourable position.

\section{Post Bretton Wood System}

After the US had abandoned the gold-backed money system, other leading economies like Great Britain and Japan were persuaded by the US president to do the same who promised improved future co-operation with the US. The US citizens were informed that the abolition of a gold-backed system was in the best interest of the US economy. President Nixon had mainly his own re-election in mind. He wanted to avoid a necessary increase of taxes which his political opponents would use against him. Obviously, economic policies were used to serve political interests. Even for specialized political analysts, dividing between political policies and economic policies is a matter of contention. The worldwide response to this drastic change of action was noteworthy. The International Monetary Fund (IMF) was created in the same year the Bretton Woods system was introduced as a means to

$$
\text { https://doi.org/10.24035/ijit.20.2021.215 }
$$


ensure the success of the fiat system. It was designed to impose its major financial objectives on economies all over the world. In response, Muslim countries held their first international Islamic economic conference in 1976 (Ahmad 1976), five years after the introduction of the fiat monetary system. Academic papers were presented which discussed issues such as a possible harmonization between Islamic economic thought and the all-dominating western economic system.

Participants of the conference attempted to stress the importance of Islamic economic theory and the inherent flaws and weaknesses of capitalist theory. Zarqa (1976) acknowledged the existent gap between the views of traditional Muslim jurists and secular Muslim economists. He pointed out the need to bridge this gap and the need to harmonize between the principles of Islamic and Western economics. Kahf (1976) attempted to produce evidence for the superiority of Islamic economic theory over capitalist theory. He argued that consumers were the main benefiters in an Islamic economy. He insisted that the Muslim duty to pay alms in form of zakat, was a major means of redistributing wealth unique to an Islamic economy which constituted the core difference between an Islamic economic system and the capitalist system. Uzair (1976) discussed some of the conceptual and practical aspects of interest-free banking. He pointed out that interest (riba) formed the backbone of any investment in the capitalist system. He offered a solution by advising banks to act as intermediaries between depositors and investors in a system called mudarabah. In that way, banks would no longer investing funds which served own interests and distribute the profit among its customers. Abu Saud (1976) exposed the causes and predicaments associated with an interest-based economic system. According to him, fiat money did not deserve to be called money in its original sense because real money did not depreciate and its value remained the same after use. Furthermore, Islam did not limit Muslims to a particular monetary theory. Al-Jarhi (1976) defended the efficiency of interest-free monetary economies. He criticized fiat money as a viable means of exchange on the ground that fiat money was an artificial product of governments and private investors.

The practice of adding interest payments on loans was generally condemned as prohibited by Islamic law. Faridi (1976) examined fiscal policy in the capitalist context and the Shari ah. He encouraged a minimum mixture of capital from an interest-free economy and interest-based economy which would encourage flight of capital from the former to the latter and thereby vitiate the 'investment effect' which in return could be used for alms (zakat). He concluded that the prohibition of interest ( $r i b a$ ) was just one part of an Islamic economic policy, zakat being the positive aspect and riba its negative aspect. Gilani (1976) discussed economic theory, policy, and practice. He acknowledged the existing competition between secular Muslim economists to create a common basis to establish sound and viable Islamic economic principles. He concluded that a successful Islamic economic strategy must be based on a correct assessment of the socio-philosophical environment of our time. Chapra (1976) ascertained that Islam was a wholesome religion that did not separate between economic and religion. He pointed out that the major difference between the Islamic economic system and the capitalist and socialist systems was that an Islamic economy achieved the equitable distribution of income within the framework of individual freedom. It included moral and legal imperatives to safeguard public interest, moral constraints against unearned income, and social obligations to ensure a just distribution of income and wealth. On the other hand, the capitalist system recognized equitable distribution of income but this recognition was the outcome of group pressure. In the socialist system on the other hand, equitable distribution demanded the negation of individual freedom.

This first international Islamic economic conference of 1976 was the first conference to address the predicaments of the fiat economic system. Although a brilliant idea, its conclusions and actual achievements were but mediocre, mainly because the conference had no specific focus and tangible agenda. No distinct methodology was applied and subsequently put into effect and it leads to no effective measures being decided and implemented to establish the fundamentals of a unified Islamic

$$
\text { https://doi.org/10.24035/ijit.20.2021.215 }
$$


economy in practice. The majority of participants were secular minded Muslim scholars who ignored any notion of a return to the gold dinar as a fixed and stable currency for all Muslim countries. Although all of them acknowledged the disastrous consequences paper currency had on the economies worldwide, they provided no viable solution or way out of this dilemma.

The poorly presented idea was certainly that voiced by Faridi who suggested a mixture of both halal 'interest-free capital' and haram 'interest based capital' profits and the use of a portion of it as alms (zakat) for the betterment of the Muslim ummah. He also encouraged the transfer of Muslim capital to the Western world to be used in "unpurified investments" to reap returns for the Muslim community. This already fairly common practice explains the present condition of the Muslim world which invests heavily in the Western market which is ruled by interest-based (riba) financing. One may raise the suspicion that Faridi does not at all comprehend the implications of his suggestion: He does no less than ask his fellow Muslims to promote a practice which is strictly prohibited (haram) in Islam. Faridi goes even further by adding that interest is just a "trivial" issue in the Islamic economic system and barely worth notice. Gilani - who has a background in oriental studies - does at no point mention Shari'ah rulings on the political means of instituting an Islamic economic system. He fails to specify that Islam is the only religion which does not separate between religion and politics.

Zarqa subjects Islamic economic thought to western theory by conceding that there exist "Islamic tenets that are relevant to economic behavior". However, Zarqa is one of the few who discusses the salient qualities of Islamic economic theory and acknowledges the possibility of instituting a future Islamic economic system. Chapra combines an Islamic approach by justifying the failure of western economic system with the need to eradicate the unjust nature of the western economic system and replace it with an Islamic alternative model. Yet, no paper presented at the conference ever so slightly touched upon a possible return to a gold dinar monetary system or even recognized the relevancy of gold and silver to a stable and independent Islamic economic system.

\section{Muslim Responses to the Fiat Economic System}

After the first international Islamic economic conference, a second attempt was made to respond to the demands of a modern western-dominated economy. In 1981 a meeting organized by the Organization of Islamic Conference (OIC) was held at the Masjid al-Haram in Makkah where the Sauidi Arabian king Khalid proposed the creation of an 'Islamic Fiqh Academy'. The intention was to create a platform for Muslim economists and jurists together from all parts of the world who would propose answers to current economic problems. The OIC accepted the suggestion and the establishment of the Islamic Fiqh Academy was approved. In 1982, the Islamic Foreign Ministers Conference in Nigeria approved the bylaw of the academy and the OIC secretariat was instructed to establish the academy in accordance with the bylaw. In 1983, a founding meeting was held in Makkah attended by an international group of representatives who approved the bylaw with some modifications which were then approved by the Islamic Foreign Ministers Conference (Usmani 1997). Thereafter, the Fiqh Academy affiliated to OIC was founded and in 1989 the Fiqh Academy of India was founded respectively.

After the establishment of the fiqh institution, there was no response to the fiat monetary system until 1985 (Al-Sallami, n.d.). -This phenomenan explains how weak and reluctant Muslims react to an epidemical situation that needed urgent reaction. Additionally, the former Prime Minister of Malaysia in 2002, Dr. Mahathir Muhammad champions the new era call for gold standard economy among Islamic states till today only verbal response in an unconcerned approach and manner Muslim scholars and elites answered to this call. The Fiqh Academy began its work by defining the term "money" (thamaniyyah) and producing a justification for the use of banknotes as replacement of gold

$$
\text { https://doi.org/10.24035/ijit.20.2021.215 }
$$


and silver. The matter of thamaniyyah is as old as Islamic jurisprudence. Identifying the effective cause of prohibition of interest ( riba) in Islamic hadith sources is a matter of contention between the four prominent Sunnite schools of jurisprudence.

\section{The Classical Islamic Scholars Definition of Money}

The first transactions were based not on money but barter trade where goods were exchanged for goods or services for services. Only later, goods and services were paid with precious stones or other valuable material, to be followed by precious metals such as gold and silver. Muslim civilization adopted the use of the Persian dinar and dirham as a medium of exchange. There are three undisputable facts that we must state here: Firstly, that the introduction of money eliminates or reduces the problem posed by barter trade; secondly, that gold and silver became the most widely accepted medium of transaction; and thirdly, that other means of exchange such as easily destructible banknotes fall short of fulfilling its functions and thus constitute no viable alternative to gold and silver.

The Prophet responded to the necessity to regulate the unrestricted usage of money and other Arab staple foods and sanctioned the way exchange should be done. Numerous traditions are related on business transactions which involved money, such as the following:

It was reported by Abi Sa'id al-KhuÌri that the Prophet (peace be upon him) had said: "Do not sell gold for gold except the same for the same and do not overvalue one above the other; and do not sell silver for silver except the same for the same, and do not value one silver above the other and do not sell anything in impurity" (Al-Bukhari: 2177 and Muslim: 1584).

There are numerous interpretations of the above stated tradition. While all unanimous on its authenticity they differ on the effective cause which made compelled the Prophet to forbid the sale of gold for gold and extended to those five articles not mentioned in this version of the tradition. All prominent schools of law have tried to identify the effective cause of this rule. It suffices to summarize their varying conclusions as follows:

1. Maliki, Hanbali/Ahmad, and Shafi'i agreed that the effective cause in gold and silver was a type of money (jins al-thamaniyyah).

2. Abu Hanifah, Ahmad, and al-Shafi'i (old opinion) agree that the effective cause in wheat, barley, dates and salt was that it was measured and staple food (mat'umah).

3. Abu Hanifah concluded that it was weight (wazn) and not money. Additionally, he opined that the effective cause in barley, wheat, salt, dates, etc. was genus (jins) in all.

4. Maliki maintained that the effective cause in barley, salt, wheat, dates, etc. was cash crops ('iqtiyat) and storability ('iddikhar) and agreement of genus.

5. Al-Shafi'i solely arrived at the effective cause of dates, salt, barley etc. as mat'umah 'staple food' only without any condition save agreement of genus.

In conclusion, the traditional definitions of money and the effective cause pronounced by each school remain valid today. There are those who confined the effective cause to the six articles including gold and silver and that it cannot be extend to other articles. The Malikites extended the effective cause to money types and measurable food items. Their conclusions were straightforward and gold and silver is maintained as the major currency.

The Contemporary Definition of Money

https://doi.org/10.24035/ijit.20.2021.215 
Although no agreement was reached on what the effective cause of the tradition narrated above is, all contemporary jurists agree that the introduction of money ended the problems posed by barter trade. Also agreed upon is that both the Quran and Sunnah prohibit interest (riba) and its components in all forms of business transactions. The ultimate purpose of Islamic financial transactions is economic justice and the welfare of the Muslim community. The first International Islamic Economic Conference held in 1976 resolved the establishment of an Islamic economic system but maintained the stand of using fiat money or banknotes as a medium of exchange - albeit not stated verbatim. As mentioned above, the Fiqh Academy of Makkah decided Resolution No D2/71406 in 1985 which concluded that:

Firstly, banknotes were considered independent currency units and for all intents and purposes governed by the same rules as gold and silver currencies which made obligatory alms (zakat) obligatory on them. Both types of usury, namely, usury of excess (riba al-fadl) and/or credit usury (riba al-nasi'a) were considered prohibited because the effective cause of the unit of price (thamaniyyah) was present in them as in gold and silver analogous to banknotes.

Secondly, likewise, banknotes were considered a separate genus according to the varying issuing authorities of currency all over the world. Thus, Saudi Arabian banknotes constituted an independent genus and U.S. American banknotes another.

The same matters continued to be discussed by the Fiqh Academy affiliated to OIC on its two following sessions held in 1987 and another fifth session held in 1988. Resolution No (9) D/3/07/86 stated that banknotes were considered currency since they shared all attributes of currency and constituted valid units of pricing. All legal rules on gold and silver applied to them in regard to interest, zakat, etc. The Academy's definition was worded so general that it included legal rules on currency-exchange, dormant partnership (mudarabah), lease, reward, partnership and all other forms of transactions. The Fiqh Academy of India followed suit in its resolution of 1991.

\section{A Critical Analysis of Contemporary Legal Rulings}

It may or may not be convincing to draw the conclusion that the Fiqh Academy's ijtihad was influenced by the resolution of the First International Islamic Conference in 1976. As it were, few obvious points could be discussed briefly as follows:

\section{Banknotes Replaced Gold and Silver and All Islamic Legal Rulings on Gold and Silver Apply to It}

Contemporary Muslim scholars accepted the use of banknotes without exception. The fact that "all Shari'ah rulings apply to it" as in gold and silver is based on the unfounded claim that gold and silver are equally valid as "money" in the eyes of Allah as modern banknotes. This must be regarded a mere political means of justifying the status of banknotes in an Islamic economic system which had been the underlying aim of the First International Islamic Conference. The Muslim jurists who passed this legal judgment, however, presented no tangible reason for such a replacement. Banknotes are being used in all forms of business transactions in the Muslim world, although when it comes to the characteristics of paper money - such as its perishability and lack of inherent material value -banknotes fail to qualify as a valid substitute.

https://doi.org/10.24035/ijit.20.2021.215 


\section{Contemporary Muslim Jurists Based Their Acceptance of Banknotes in Substitution of Gold} and Silver on Analog Deduction (Qiyas).

Al-Shawkani defines qiyas as the extension of a rule of an original case to a new case based on the fact that the latter has the same effective cause as the former (Kamali, 2008). Its validity as a legal Islamic ruling is based on the evidence found in the Quran and Sunnah. In the Quran Allah says "...Rush to the remembrance of God and leave buying and selling..." (al-Jumu'ah: 9). By analogy this prohibition of buying and selling after the call to the congregational Friday prayer extends to other transactions as well if their cause is a diversion from prayer. Similarly, the Prophet was reported to have said "The killer shall not inherit (from his victim)" (Musnaf Abul al-Razzaq, 9/17786). By analogy, this means that a killer cannot benefit from the will of his victim (Badran 1984; Kamali 2008). Qiyas consists of four essential elements, Asl (original case), hukm al-asl (legal injunction), far' (parallel case), and 'illah (effective cause). Conclusively, a relationship has to be established between the effective cause of the original case and the parallel case. Applying these principles of analogy to banknotes in replacement of gold and silver as the effective cause, we reexamine it as below.

Unlike banknotes, gold and silver can be deposited and stored over long periods of time without decay or depreciation. Both have always been and continued to be cherished metals by all civilizations and people, irrespective of their geographical location or religious orientation. Gold and silver are commonly regarded valuable and desirable metals without any necessary enforcement by issuing authorities. Banknotes or paper money on the other hand have no intrinsic value and only serve as artificial units of price through official enforcement by the authorities. Although the market price of gold and silver may fluctuate, both retain minimum value and serve as stable and reliable deposits while the value of banknotes completely depend on the financial and economic status of its issuing authorities.

The claim that gold and silver are analogous to banknotes is unfounded because using the unit of price as the effective cause ('Illah) is not unjustified. The effective cause must be based on the intrinsic value of a material, not its artificially created value which is purely functional. As the effective cause ought to be identified not the function of money but its intrinsic value. In the same manner alcohol was prohibited for consumption based on its intrinsic nature of being an intoxicating substance'. Another argument against the claimed equal status of gold and silver with paper money is that gold and silver have independent value which does not require artificial agreements of exchange between governments. If we agree that banknotes can substitute gold and silver and accept as effective cause the unit of price, we expect that any country's currency can be exchanged for equal value into any another currency, which is not the case. Certain "weaker" currencies are not accepted for exchange while others are. On the other hand, gold and silver can be sold anywhere across borders and they are accepted in Nigeria just as readily as in Saudi Arabia, Japan or Great Britain. Only strong currencies such as the U.S. Dollar, the British Pound Sterling or the Japanese Yen are accepted benchmark currencies and readily exchangeable. The reason for this is the functional value of these strong currencies which entirely depend on the political and ultimately economic status of dominance of their issuing countries. Paper is paper and the intrinsic value of all banknotes is the same, yet, it is other factors which determine their functional value.

\section{Banknotes are Considered Each as a Separate Genus According to the Different Issuing Authorities} of Currency

Saudi Arabian Riyal banknotes are one independent genus and U.S. American banknotes are another. The classification of world currencies as different genus based on the authority that produced or

$$
\text { https://doi.org/10.24035/ijit.20.2021.215 }
$$


issuing them is not acceptable. The analogy is unfounded and false. Paper money either does replace gold and silver in all its currency forms or it does. There can be no partial replacement of some currencies with the exclusion of others i.e. weaker currencies such as Malaysian Ringgit etc. represents silver and stronger currencies such as US dollar etc. represents gold. As pointed out earlier, gold and silver have always been the treasured metals by all of mankind, a fact that Allah, The Knower and Sustainer of this world and all that is beyond, has acknowledged and consented upon. Banknotes are issued by numerous different authorities all over the world, with a different design and marking, but all from the same basic material, namely paper. The Malaysian Ringgit is in itself nothing but printed paper and so is the U.S. Dollar. Their practical or functional value has been assigned to them by their issuing authorities and depends entirely on their economic and political status.

OIC Affiliate Fiqh Academy of Makkah Broadened the Definition of Money

To an extent as to include all existing legal rules on currency-exchange, mudarabah, lease, reward, and all other transactions, in our opinion - incorrect definition, some contemporary Muslim jurists accept the permissibility of exchanging \$1 USD (representing gold) for RM 3.5 (representing silver). In their understanding, it is permissible (halal) to sell banknotes for banknotes with unjustified excess. Such a decision opened the door for all the inappropriate ways of selling and buying currencies as if they were commodities as it is practiced today on a large scale. It drastically altered and ultimately alienated money from the purpose it had initially been created for, namely, to serve as a legitimate means to allow for the neutral exchange of goods and services. Unfortunately, currency has become an end in itself. Muslim jurists have decided on its permissibility and lawfulness, albeit without a thorough and sufficiently critical evaluation of the circumstances.

\section{The Exchange Rate}

The conversion rate of currencies -- also known as the 'hit rate'-- is derived by the number of sales realized as a \% of the number of sales calls or enquiries received. It is also known as batting rate. Sales call is understood as the pre-arranged face-to-face meeting of a salesperson and a customer or prospective customer for the purpose of generating sales (Business Dictionary 2009). However, fixing exchange rates of currencies which are the rate of converting one currency to another strictly depends on the local demand for foreign currencies and their local supply, the country's trade balance, strength of its economy and other factors.

In the discussion of the replacement of gold and silver with banknotes, the matter of exchange has not been taken into consideration. Who are the parties who fix these exchange rates? To which institution do they belong to and which market do they represent? Exchange rates have wide implications, not only of economic but also of political nature. Theoretically or ideally, exchange rates ought to be fixed by a neutral body which represents a global market. In reality, however, the exchange rates are fixed according to the interests of a U.S. dominated market economy by an exclusive group of people representing exclusive financial institutions. Therefore, Muslim jurists deciding on such matters as the permissibility of the replacement of gold and silver and international financial systems have to take these realities into due account so as not to end up with an apologetic ijtihad which condoles the self-serving practices of a dominating power.

\section{The Consequences of Contemporary Fatwas (Legal Rulings) on the Replacement of Gold Currency}

https://doi.org/10.24035/ijit.20.2021.215 
It is pertinent to note that the contemporary scholars have associated multiple effective causes such as unit of price etc. to justify their legal rulings on the substitution of gold dinar for banknotes. Inconsistent identification of "effective cause" was as a result of the multiple legal bodies. It appears each body assumed to be unique and intended to produce something which would distinguish it from others. This claim could be justified based on the methods and results of their ijtihad. The question is: Is there any need for creation of multiple fiqh academies i.e. of Makkah, OIC affiliate, India academies respectively?

In the scholars' ijtihad, it seems exchange rate and systems were left out of consideration. They only considered the replacement without reservation. Their conclusions have reached decades yet to the best knowledge of the researcher, there is no published academic work revisiting the issue or any conference to rectify these errors in their ijtihad. For only Allah know His soldiers, in His greatness intellectuals and politician have been arose to defend the course of Allah through seminars, conferences and symposiums on gold dinar monetary system.

Notably among intellectuals are Imran Hosein, Umar Vadillo, Kameel Mydin Meera just to name few and solely the only Muslim politician that advocated for non-replacement of gold dinar for banknotes is the former Malaysia Prime Minister Dr. Tun Mahathir who publicly denounced the banknotes and set the pace for returning of gold dinar era. None of the member of the Fiqh Academies have publicly criticized and revoked their fatwas on substitution of gold dinar for paper money.

To justify the claims of the intellectuals and politician that supported gold dinar, Allah "The Almighty" has vindicated the human manipulations and extent of insecurity of the fiat monetary system. Recently, issue of conventional banks such as Barkley Bank and others in the western world (first world) in manipulation of the exchange rates was exposed (Hassan et. al. 2016). Specifically, Olorogun (2010) in his Master's dissertation entitled “Gold Dinar as Medium of Transaction among Muslim Countries: A Fiqh Perspective" stated that exchange rates are fixed by group of people not determined by the market forces of demand and supply. This was further substantiated by U.S. Department of Treasury (2019) that the U.S. government vows to combat unfair currency practices particularly unwarranted intervention in the currency markets. Similarly, The New York Times reported that the U.S.-China trade war has migrated to currency war, as U.S. government accused China of currency manipulation (Swanson 2019).

The consequence on the contemporary scholars in the fiqh academies is disposure of shallow thinking faculty, uninformed scholars or intellectual corrupted scholars as the case may be. The greatest of the consequence is the perceived improper image of "Islam" as a divine religion with standard constitution by the non-Muslims and Muslims alike. Their fatwas seems influenced or motivated by eco-political egoism. Perhaps, some people would perceive Islamic fatwas as games and ineffective process of legal system deployed through religion. This is another great lesson for the contemporary scholars who claimed the substitution of gold dinar for fiat monetary system that their fatwas was against Allah's wish. Allah have explores both human beings and nature to propagate the need for change of international monetary order from fiat and capitalist system to gold dinar monetary system.

It is obvious the contemporary scholars' legal rulings on substitution of gold dinar for fiat money are erroneous in all forms. Considering it form Islamic legal standard, the replacement reasons presented were vague and ambiguous. The holy Prophet (peace be upon him) have warned Muslims to avoid vagueness in all forms as it may lead to sins against Allah's wills. Academically, it disposed the level of the scholars' understanding of the capitalists' oriented economic system, even when it seems they know it but deliberately, pretended not to know. Lastly, politically it places the Muslims and other third world nations as prey for the advanced nations (first world). The Muslim countries vulnerability goes beyond economy dependence on the first world nation to the intellectual and technological power in the global arena.

$$
\text { https://doi.org/10.24035/ijit.20.2021.215 }
$$


Thus, there is need for unification of fatwas or the creation of institutional ijtihad wherein all Muslims would abide by the legal rulings from this institution regardless of their region or school of thoughts. In addition, there is need to establish strong motivational programs where scholars with pure jurisprudent background were trained or thought at least basic conventional economic and finance knowledge. Similar consideration should be given to the Muslim conventional oriented scholars and be thought the Islamic jurisprudent of commercial dealings. These are long-term program, nevertheless, it would yield best results that would minimize or eradicate the predicament currently facing the Muslim world and its financial institutions.

\section{References}

Al-Bukhari, Muhammad bin 'Isma'il bin 'Ibrahim. 1987. Al-Jami' al-Sahih. Based on Ibn Hajar al'Asqalani's Arrangement. al-Qahirah: Dar al-Shanb.

Abu Saud, Mahmud. 1976. Money, interest and qiraì. In, Ahmad Khurshid (Eds.). Studies in Islamic Economics: A Selection of Papers, Presented to The First International Conference on Islamic Economics. Delhi: Taj Offset Press.

Abu Umar, F.A, Abu Talib M. M. \& Olorogun, L.A. 2020. Takyif fiqhi on the permissibility of ijarah mawsufah fi al-dhimmah: a critical analysis. International Journal of Islamic Thought. 17: 1-14. https://doi.org/10.24035/ijit.17.2020.165

Ahmad, K. 1976. Economic development in an Islamic framework. In, Ahmad Khurshid. (Eds.). Studies in Islamic Economics: A Selection of Papers, Presented to The First International Conference on Islamic Economics. Delhi: Taj Offset Press.

Ahmad, bin Hanbal Abu Abdullah al-Shaibani. n.d. Musnad al-Imam Ahmad bin Hanbal. Al-Qahirah: Mu'sasah Qurtubah.

Al-Jarhi, Mabid Ali Muhammad Mahmoud. 1976. The relative efficiency of interest-free monetary economies: the fiat money case. In, Ahmad Khurshid (Eds.). Studies in Islamic Economics: A Selection of Papers, Presented to The First International Conference on Islamic Economics. Delhi: Taj Offset Press.

Al-Sallami, al-Mukhtar Muhammad. n.d. In, M. H. Kamali (ed. \& transl.), Al-Qiyas \& Its Modern Application (Eminent Scholars Lecture No: 15). n.l. Islamic Research and Training Institute.

Badran, Abu al-'Ainain. 198). Usul al-Fiqh al-Islami. In, Badran Abu al-'Ainain Badran (E.ds), Alexander: University Youth Foundation.

Bernstein, P. L. 2008. A Premier on Money, Banking and Gold. Hoboken: John Wiley \& Sons, Inc.

Business Dictionary (2009). Definition of Exchange Rate. www.BusinessDictionary.com. Retrieved: 10th September, 2009.

Chapra, U. U. 1976. The Islamic welfare state and its role in the economy. In, Ahmad Khurshid (Eds.), Studies in Islamic Economics: A Selection of Papers, Presented to the First International Conference on Islamic Economics. Jeddah. Delhi: Taj Offset Press.

Faridi, F. F. 1976. Zakat and fiscal policy. In, Ahmad Khurshid (Eds.). Studies in Islamic Economics: A Selection of Papers, Presented to the First International Conference on Islamic Economics. Delhi: Taj Offset Press.

Fiqh Academy of Makkah. 1988. Resolutions on Second Conference. Jiddah: The Fiqh Academy of Makkah.

Fiqh Academy of India. 2004. Resolutions on Conferences 1-26. India: The Fiqh Academy of India.

Ibn Khaldun. 1406. Muqaddimah Ibn Khalidun. F. Rosenthal, (Transl.). An Introduction to History. N. J. Dawood, (ed.), B. B. Lawrence "New Introduction". Abridged (ed.), Princeton: Princeton University Press. 
Gilani, Ijaz Shafi.1976. The political context of Islamic economics: high and low road strategies. In, Ahmad Khurshid (Eds.). Studies in Islamic Economics: A Selection of Papers, Presented to the First International Conference on Islamic Economics. Delhi: Taj Offset Press.

Hassan, T.A.; Mertens, T.M. \& Zhang, T. 2016. Currency Manipulation. Federal Reserve Bank of San Francisco Working Paper Series. https://www.frbsf.org/economic-research/files/wp201615.pdf Retrieved: March 9, 2020

Hosein, I. N. 2007. The Gold Dinar and Silver Dirham: Islam and the Future of Money. San Fernando: Masjid Jemi'ah City of San Fernando.

Kahf, Monzer. 1976. A contribution to the theory of consumer behaviour in an Islamic society. In Ahmad Khurshid (Eds.). Studies in Islamic Economics: A Selection of Papers, Presented to The First International Conference on Islamic Economics. Delhi: Taj Offset Press

Kamali, M. H. 2008. Principles of Islamic Jurisprudence. In, Kamali, Mohammad H. (e.d). Principles of Islamic Jurisprudence. Cambridge: The Islamic Texts Society.

Muslim, Abu al-Hussain Muslim bin al-Hajaaj al-Qushairi. n.). Al-Jami' al-Sahihi al-Musamma SahiÍ Muslim. Beirut: Dar al-Jayl \& Dar al-Afaq al-Jadidah.

Olorogun, L. A. 201). Gold Dinar as Medium of Transaction among Muslim Countries: A Fiqh Perspective. Masters Thesis, Kuala Lumpur: International Islamic University Malaysia, Library

Swanson, A. 2019. The U.S. Labeled China a currency manipulator. here's what it means. The New York Times. https://www.nytimes.com/2019/08/06/business/economy/china-currencymanipulator.html?auth=link-dismiss-google1tap. Retrieved: March 9, 2020.

Usmani, M. T. 1997. Islamic Fiqh Academy: Deliberations on the 97 Meeting. In, Baig Khalid (transl.). http://www.albalagh.net/qa/ifa.shtml. Retrieved: $2^{\text {nd }}$ April, 2010.

United States' Department of Treasury. 2019. Report to Congress: Macroeconomic and Foreign Exchange Policies of Major Trading Partners of the United States. https://home.treasury.gov/system/files/206/2019-05-28-May-2019-FX-Report.pdf Retrieved: March 9, 2020

Uzair, Mohammad. 1976. Some conceptual and practical aspects interest-free banking. In, Ahmad, Khurshid (Eds.). Studies in Islamic Economics: A Selection of Papers, Presented to The First International Conference on Islamic Economics. Delhi: Taj Offset Press.

Zarqa, Anas. 1976. Islamic Economics: An Approach to Human Welfare. In Ahmad Khurshid (Eds.), Studies in Islamic Economics: A Selection of Papers, Presented to The First International Conference on Islamic Economics. Delhi: Taj Offset Press 